\title{
Gender Difference in Environmental Attitude and Behaviors in Adoption of Energy-Efficient Lighting at Home
}

\author{
Eunsil Lee ${ }^{1}$, Nam-Kyu Park ${ }^{2} \&$ Ju Hyoung Han ${ }^{3}$ \\ ${ }^{1}$ School of Planning, Design and Construction, Michigan State University, USA \\ ${ }^{2}$ Interior Design Department, College of Design, Construction and Planning, University of Florida, USA \\ ${ }^{3}$ Department of Community Sustainability, Michigan State University, USA \\ Correspondence: Eunsil Lee, School of Planning Design \& Construction, 201L Human Ecology building, \\ Michigan State University, East Lansing, MI 48824, USA. E-mail: leeeunsi@msu.edu
}

Received: July 6, 2013 Accepted: August 6, 2013 Online Published: August 14, 2013

doi:10.5539/jsd.v6n9p36 URL: http://dx.doi.org/10.5539/jsd.v6n9p36

\begin{abstract}
During the past decade, residential consumers' adoption of energy-efficient lighting has increased slowly in the United States. To identify residential consumers' attitudes and behaviors toward the adoption of energy-efficient lighting, this study examined gender differences in (1) residential consumers' environmental behaviors in relation to lighting practice and (2) background variables of environmental behaviors including ecological value orientation, subjective norms, and lighting perceptions. Data were collected from residents in a Midwestern town in the United States; 303 surveys were used for the analysis. The findings indicated that women were more likely to engage in energy-saving practices and were more willing to pay a higher price for energy-efficient light sources. However, no gender differences emerged in the purchase of energy-efficient light sources and support for policies banning inefficient incandescent light sources. In terms of environmental attitudes, women scored significantly higher in altruistic and biospheric values than men, yet there was no difference in egoistic values. In addition, compared to men, women scored higher on subjective norms in the adoption of energy-efficient lighting. Finally, women were more likely to perceive lighting as an important factor in their everyday lives, prefer incandescent lighting, and perceive fluorescent lighting as having negative effects on human health. This study expects to contribute to the theoretical knowledge of gender differences in environmental research and provide policy makers and consumer scientists with understanding about the role of gender in residential consumers' adoption of energy-efficient lighting.
\end{abstract}

Keywords: energy-efficient lighting, gender, environmentally responsible behavior

\section{Introduction}

Over the past decade, the American lighting market has been moving toward more energy-efficient lighting technologies (U.S. Department of Energy [DOE], 2012). According to the 2010 U.S. Lighting Market Characterization report (DOE, 2012), all sectors-including commercial, residential, outdoor, and industrial sectors-have become more efficient by replacing inefficient incandescent lamps with energy-efficient lamps, such as fluorescent or compact fluorescent lamps (CFLs). However, the DOE's (2012) report indicated that the highest energy-consuming lamps in the residential sector are still incandescent lamps, accounting for approximately $78 \%$ of the sector's total consumptions. Although energy consumption for lighting can be reduced by $50 \%$ to $75 \%$ by using more energy-efficient lighting, such as CFLs or light-emitting diode (LED) lamps, residential consumers' adoption of energy-efficient lighting technologies has been slow, not only in the United States (DOE, 2012), but also in other countries (Reynolds, DeSisto, Murray, \& Kolodinsky, 2007). Considering that $71 \%$ of all lamp installations nationwide in the United States are used in the residential sector (DOE, 2012), it is critical to seek effective ways to promote residential consumers' adoption of energy-efficient lighting by identifying why many households are still not willing to use energy-efficient lighting.

Consumers' environmental behaviors have been increasingly explored in terms of consumers' purchase of green products or energy-consumption behaviors. Most studies have generally focused on psychological and contextual reasons to explain why individuals do or do not engage in environmentally responsible actions (e.g., Jakob, 2007; Manzan \& Zerom, 2006; Rehdanz, 2007). Various factors have been identified as influential predictors of 
consumers' environmental behaviors, including knowledge and values as well as situational and economic barriers (e.g., Steg, 2008). However, few studies have focused on whether consumers' environmental behaviors differ across sub-groups, such as gender within the target population (e.g., Blocker \& Eckberg, 1997; Zelezny, Chua, \& Aldrich, 2000). It has been necessary to identify whether clear differences exist in environmentally responsible behaviors among sub-groups based on household characteristics (Mills \& Schleich, 2012) or socio-demographics (Reynolds et al., 2007). In order to consider if differentiated promotion strategies or policies are required for different sub-groups to more effectively promote environmentally responsible behaviors, it is critical to identify if and how environmental behaviors and attitudes differ among sub-groups of the target population.

In previous research, stronger pro-environmental attitudes and behaviors have been identified more often in white (Johnson, Bowker, \& Cordell, 2004), younger (Corbett, 2005), more educated (Casey \& Scott, 2006; Shen $\&$ Saijo, 2008), and female individuals (Zelezny et al., 2000). Among the demographic characteristics, the role of gender has been studied most in terms of environmentally responsible behaviors (e.g., Blocker \& Eckberg, 1997; Parikh, 1995; Zelezny et al., 2000) as well as household energy conservation practices (e.g., Carlsson-Kanyama \& Lindén, 2007; Gilg, Barr, \& Ford, 2005; Räty \& Carlsson-Kanyama, 2010). Although previous studies have generally indicated that women have a higher level of pro-environmental attitudes and behaviors than men (Matthies, Kuhn, \& Klockner, 2002; Sherkat \& Ellison, 2007; Torgler, García-Valiñas, \& Macintyre, 2008; Zelezny et al., 2000), some research has also found no gender differences in environmental behaviors (Blankenau, Snowden, \& Langan, 2008) or men to be stronger environmental behavior participants (Eisler, Eisler, \& Yoshida, 2003), indicating that gender differences in environmental behaviors were inconsistent across various environmental studies.

Considering the importance of promoting residential consumers' adoption of energy-efficient lighting, it is vital to understand more accurately their environmental attitudes and behaviors toward energy-efficient lighting. However, the research on residential consumers' environmental behaviors and attitudes toward the adoption of energy-efficient lighting technologies has been limited. In particular, there is a marked absence of research about the role of gender in the adoption of energy-efficient lighting at home. In order to fill this research gap, the purpose of this study is to explore gender differences in both (1) environmental behaviors in residential lighting practice and (2) background variables of environmental behaviors, including (a) ecological value orientation, (b) subjective norms toward energy-efficient lighting, and (c) lighting perceptions.

By exploring how gender is related to the adoption of energy-efficient lighting at home, this study intended to provide policy makers, consumer scientists, and utility companies with empirical knowledge and insights about differences in consumer subgroups to help create more optimal marketing strategies, consumer education, policy development, and promotion programs to effectively tackle specific issues of different consumer groups.

\section{Literature Review}

\subsection{Gender Differences in Environmental Attitudes and Behaviors}

Since the 1990s, many studies across countries have indicated significant gender differences in environmental attitudes, consistently showing that women have higher pro-environmental attitudes than men (Heinzle, Kanzig, Nentwich, \& Offenberger, 2010; Vinz, 2009; Xiao \& Hong, 2010; Zelenzny et al., 2000). For example, Tikka, Kuitunen, and Tynys (2000) conducted an empirical study exploring students' environmental attitudes in a region of Central Finland and showed that women were more likely to be concerned about the environment than men. More recent study of Torgler et al. (2008) collected data from 33 Western and Eastern European countries. They also found that women had stronger pro-environmental attitudes. Lee's (2009) research, which was conducted in an Asian country, also concluded that women showed significantly more concern than men about the environment. Despite some exceptions, such as Mostafa's (2007) study showing that women in an Arab country appeared to be less interested in environmental issues and have lower environmental concerns compared to men, the majority of studies across countries have generally demonstrated that women have stronger pro-environmental attitudes.

However, in terms of gender issues in environmentally responsible behavior, previous studies have not arrived at a definitive finding as to whether men or women are more likely to being engaged in environmentally responsible behavior. Many studies in different regions of the globe have revealed conflicting results about the effect of gender on environmental behavior. Zelezny et al. (2000) conducted a meta-analysis of studies across 14 countries from 1988 to 1998 and found that women reported significantly more adoption of environmentally responsible behaviors than men. Similar results were shown again later with a European sample by Matthies, Kuhn, and Klockner (2002) and an American sample by Sherkat and Ellison (2007). Yet contrary results were 
shown in the study of Eisler et al. (2003), who demonstrated that men engaged in environmental behaviors more strongly than women. Many studies also revealed no gender differences in environmentally responsible behaviors (e.g., Berenguer, Corraliza, \& Martin, 2005; Blankenau et al., 2008). In particular, in terms of the use of energy-efficient lighting, no gender effects were shown in Reynolds et al.'s (2007) study, which was conducted in the Caribbean.

Furthermore, in many studies, women's higher level of pro-environmental attitude was not linked to a greater extent than men's to a higher level of pro-environmental behavior. For example, Blocker and Eckberg (1997) found no evidence that women are more likely to engage in environmentally responsible behaviors than men, although women do tend to show more concern about the environment. On the other hand, Scott and Willits (1994) reported a gender difference in environmental behavior, although no significant relationship occurred between gender and environmental attitude. According to Scott and Willits (1994), men are more likely to purchase green products, yet both men and women have similar levels of environmental concern.

To better explain causal factors of environmental behaviors, researchers claimed different types of environmental behaviors should be considered. For example, Stern (2000) environmental studies that undifferentiated types of environmental behaviors and distinguished three types of environmental behaviors: (1) environmental activism (e.g., active involvement in environmental organizations), (2) non-activist behaviors in the public sphere (e.g., support for public policies or willingness to pay higher taxes), and (3) private-sphere environmentalism (e.g., green product purchases, energy-saving behaviors, or recycling). Similarly, researchers have explained that the inconsistent results in gender differences between environmental attitudes and behaviors are related to different types of environmental behaviors. Hunter, Hatch, and Johnson (2004) categorized types of environmental behaviors into household-oriented environmental behavior (e.g., recycling) and community/society-oriented environmental behaviors (e.g., protest). According to Hunter et al. (2004), women tended to show higher participation in household-oriented private environmental behaviors, but no differences generally emerged in community/society-oriented environmental behaviors. Xiao and Hong (2010) subsequently investigated 39 environmental behavior studies: 28 on household-oriented, 17 on community/society-oriented, and 12 on both household- and community/society-oriented environmental behaviors. They found that all but two of the studies on household-oriented environmental behaviors revealed women's higher participation in private environmental behaviors while most studies consistently showed no gender differences in community/society-oriented behaviors.

These previous studies provide the theoretical background for gender differences in different types of environmentally responsible behaviors related to the adoption of energy-efficient lighting at home. The current study focused on two household-oriented environmental behaviors-namely, energy-saving practice at home and purchase of energy-efficient lighting-and two community/society-oriented behaviors-namely, willingness to pay a higher price and support for policies. Thus, we formulated Hypothesis 1:

H1. A gender difference exists in environmental behaviors related to adopting energy-efficient lighting at home:

H1-1. A gender difference exists in energy-saving practices at home.

H1-2. A gender difference exists in buying energy-efficient lighting products.

H1-3. A gender difference exists in willingness to pay a higher price for energy-efficient lighting products.

H1-4. A gender difference exists in supporting policy for banning inefficient incandescent lighting products.

\subsection{Background Variables of Environmental Behaviors}

In light of the inconclusive results of gender issues in environmental studies, scholars have tried to explain gender differences in environmental behaviors by understanding predictor variables of environmental attitudes and behaviors-in other words, background variables in less definitive term. Researchers in environmental psychology have identified several psychological constructs (e.g., value, belief, attitude, awaremess etc.) to explain why individuals might or might not choose a particular environmental behavior. This study focused on (1) ecological value orientation, (2) subjective norm (i.e., perceptions of general social pressure about behavior), and (3) perceptions toward lighting technologies and their effects on people.

\subsubsection{Ecological Value Orientation}

One of the important predictor variables where gender has a role to play is ecological value orientation. As human values predict attitude and behavior (Rokeach, 1973), putting more values on others or ecosystems might be an important background variable of environmental behaviors. According to the norm-activation model 
(NAM; Schwartz, 1977) and value-belief-norm (VBN) theory (Stern, Dietz, Abel, Guagnano, \& Kalof, 1999), helping behavior including environmental behaviors can be explained in part by three ecological value orientations: altruistic, egoistic, and biospheric values. NAM (Schwartz, 1977) and VBN (Stern et al., 1999) theory suggest that environmental attitudes, beliefs, and environmental behaviors are shaped by aggregating these three value orientations. People with egoistic value orientation are concerned about the environment for their own benefits while people with altruistic value orientation are concerned about the environment for the welfare of other people. Those with biospheric value orientation care about the environment because of its impacts on ecological systems rather than personal benefits or human survival.

Meanwhile, the gender socialization theory indicates that women are more altruistic than men because women are socialized to be more interdependent and more helpful in caregiving and nurturing roles whereas men are socialized to be more independent and competitive (Blocker \& Eckberg, 1997; Eisenberg, 2002; Gilligan, 1982; Zelezny et al., 2000). Gender socialization theory explains that women have a more pro-environmental attitude as a result of gender-based socialization processes because women, as caregivers for families and others, are considered to be more concerned about the environment while men, with the role of breadwinner, are more concerned about economics (Wehrmeyer \& McNeil, 2000). Ecofeminists have also suggested strong gender differences in pro-environmental attitude and argued that women care more about the environment because of their stronger biospheric value orientation, which is in their nature (Diamond \& Orenstein, 1990).

Empirical studies have supported the gender differences on these three ecological value orientations. Stern, Dietz, and Kalof (1993) showed that women were significantly stronger on all three types of value orientation. In a telephone survey of 1,005 California adults, Schultz (2001) found that women scored higher on all three (i.e., altruistic, egoistic, and biospheric) value orientations. In a more recent study, Swimi, Chamorro-Premuzic, Snelgar, and Furnham (2010) demonstrated that women showed higher levels of altruistic and egoistic value orientations. Accordingly, we argue that it is important to consider gender issues in value orientations in relation to the residential consumers' adoption of energy-efficient lighting. Based on the theory and empirical studies, we propose Hypothesis 2:

H2. A gender difference exists in ecological value orientations among residential consumers:

H2-1. A gender difference exists in altruistic value among residential consumers.

H2-2. A gender difference exists in egoistic value among residential consumers.

H2-3. A gender difference exists in biospheric value among residential consumers.

\subsubsection{Subjective Norms}

The effect of peer influence, or desire for social approval and acceptance, has been discussed in theoretical and empirical studies. The theory of reasoned action (TRA), introduced by Fishbein and Ajzen (1975) and later refined into the theory of planned behavior (TPB) (Ajzen, 1985), explained that perceptions of general social pressure to perform or not perform a particular behavior (i.e., subjective norms) has significant influence, along with variables such as attitude, on the process of behavior decision. Individuals might observe and follow the environmental behaviors of their social members in order to be accepted. Many studies have applied TRA or TPB to explain environmental behaviors such as recycling (Cheung, Chan, \& Wong, 1999), conservation (Kaiser, 2006), commute-mode choice (Wall, Devine-Wright, \& Mill, 2007), and technology adoption (Schepers \& Wetzels, 2007). These studies have addressed the importance of subjective norms in environmental behaviors.

Empirical studies have also indicated the subjective norm as an important background variable in which gender plays a role. For examples, Venkatesh and Morris (2000) explored the relationship between gender and subjective norms in technology adoption and found a significant gender difference. Subjective norms did not influence men's decisions at any point, yet had a significant influence on women's decision making. Lee (2009) found that women scored significantly higher than men in peer influence in behavioral choice, although both men and women perceive peer influence to be an important factor in their behavioral decision. Thus, the current study explored whether a gender difference exists in subjective norms in terms of behavioral decisions on the adoption of energy-efficient residential lighting by proposing Hypothesis 3:

H3. A gender difference exists in subjective norms for the adoption of energy-efficient lighting at home.

\subsubsection{Lighting Perceptions}

Consumers' environmental behaviors are generally related to their environmental attitudes, but, in many cases consumers' purchase of green products encompasses their perceptions of the product or the perceived importance of the product in their lifestyle (Corraliza \& Berenguer, 2000; Kollmuss \& Agyeman, 2002; Stern et 
al., 1999). Veitch and Gifford (1996) argued that energy conservation through the adoption of energy-efficient technology can succeed if policy makers and marketers understand people's perceptions about lighting and its effects. In order to understand residential consumers' environmentally responsible behaviors toward the adoption of energy-efficient lighting, it is important to understand their perceptions and beliefs about the performance of lighting technologies.

According to Banwell and Figueiro (2005), people generally prefer the warm color of an incandescent lamp while they have some negative perceptions about the health effects of a fluorescent lamp (Veitch \& Gifford, 1996). As men and women generally develop different perceptions toward atmospheric attributes, such as colors or lighting conditions of interior space (Yildirim, Akalin-Baskaya, \& Hidayetoglu, 2007), gender differences should be taken into account in consumers' lighting perceptions. Empirical studies have found significant gender differences in emotional reaction and cognitive performance to the interior lighting conditions (Knez, 1995). In Knez's study, under the same lighting color or illuminance level, women generally perceived those atmospheric attributes more prominently and showed more sensitive reactions than did men. Knez and Kers (2000) investigated the effects of indoor lighting and gender on mood and cognitive performance. They found that, regardless of lighting condition, women evaluated indoor lighting as more intense and more glaring than men. In particular, the cool and warm white lights were perceived emotionally different between women and men because the color of light with different types of lamps can convey different meaning and emotions. Leslie and Hartleb (1990) showed possible gender differences in illuminance preference by demonstrating that females preferred much lower levels of lighting than men.

According to Knez (1995), good lighting criteria should be differentiated by taking gender differences into account. However, research in this area is limited, and few studies have focused on gender issues related to consumers' perceptions of lighting technologies. To expand the understanding of gender issues in the residential lighting domain, it is important to consider residential consumers' perceptions toward lighting technologies and effects on people. Thus, we propose Hypothesis 4:

H4. A gender difference exists in lighting perceptions among residential consumers.

H4-1. A gender difference exists in perceived importance of lighting.

H4-2. A gender difference exists in perceived health effects of fluorescent lighting.

H4-3. A gender difference exists in preference for incandescent lighting.

To this end, this study first examined the relationships between environmental behaviors and background variables; then explored whether a gender difference occurred in each behavior and background variable. When a gender issue was observed, this study compared the patterns between men and women.

\section{Methods}

\subsection{Sampling and Data Collection}

Residents in a Midwestern town in the United States completed a survey. Survey participants were selected using systematic random sampling from the list of addresses provided on the township's website. About 2,000 surveys were sent out, and 326 surveys were returned by mail, resulting in a $16.3 \%$ response rate. Although this response rate is relatively low, Alreck and Settle (1995) indicated that $5 \%$ to $30 \%$ is the typical response rate for a mail survey. Thus, we considered this response rate to be acceptable. In total, 303 surveys were used for further analysis after excluding incomplete surveys $(\mathrm{n}=15)$ and surveys that did not indicate the respondent's gender $(\mathrm{n}=8)$.

\subsection{Measurement}

\subsubsection{Environmental Behaviors in Residential Lighting Practice}

Respondents' environmental behaviors in residential lighting practice were measured based on the work of Stern (2000) and Hunter et al. (2004). Using a 7-point Likert scale $(1=$ strongly disagree to $7=$ strongly agree $)$, four environmental behaviors were measured: two for household-oriented behaviors and two for community/society-oriented behaviors. The two household-oriented behaviors were (a) energy-saving practice (i.e., As I leave the room, I make sure that I turn off the light) and (b) buying energy-efficient light bulbs (i.e., When I buy lighting products, I look for the energy-efficient ones). The two community/society-oriented behaviors were (a) willingness to pay a higher price (i.e., I would be willing to pay higher prices for energy-efficient light bulbs to protect the environment) and (b) support for the policy (i.e., I would support government policies banning energy-wasting incandescent light bulbs for homes). 


\subsubsection{Ecological Value Orientations}

The measurement of ecological value orientation was adopted from the VBN theory (Stern et al., 1999) (see Table 1).

The altruistic value scale consisted of four 7 -point Likert scale statements $(1=$ not important to $7=$ very important). Survey respondents rated the following statements: The guiding principles in your life are (a) equality; (b) social justice; (c) helpfulness; and (d) a world at peace. The overall mean of the four items was 5.91 (S.D. $=.93$ ), and the reliability of this aggregated scale was $\alpha=.79$.

The egoistic value scale consisted of five 7 -point Likert scale statements $(1=$ not important to $7=$ very important). Survey participants responded to the following statements: The guiding principles in your life are (a) social power; (b) wealth; (c) authority; (d) influence; and (e) ambition. The overall mean of the five items was 4.36 (S.D. $=.92$ ), and the reliability measure of this multi-item scale was $\alpha=.69$.

The biospheric value scale consisted of four 7-point Likert scale statements $(1=$ not important to $7=$ very important). Survey participants indicated their response to the following statement: The guiding principles in your life are (a) respecting the earth, (b) preventing pollution, (c) protecting the environment, and (d) unity with nature. The overall mean of the four items was $5.87($ S.D. $=1.04)$, and the reliability measure of this multi-item scale was $\alpha=.91$.

Table 1. Ecological value orientation measurement scale, mean, and reliability

\begin{tabular}{|c|c|c|c|c|}
\hline $\begin{array}{l}\text { Variables } \\
\text { Ecological } \\
\text { value } \\
\text { orientation }\end{array}$ & Categories & Items & Mean* & Reliability \\
\hline \multirow{13}{*}{$\begin{array}{l}\text { Ecological } \\
\text { value } \\
\text { orientation }\end{array}$} & Altruistic value & 1. Equality: equal opportunity for all & 5.91 & $\alpha=.79$ \\
\hline & & 2. Social justice: correcting injustice, care for the weak & & \\
\hline & & 3. Helpfulness: working for the welfare of others & & \\
\hline & & 4. A world at peace: free of war and conflict & & \\
\hline & Egoistic value & 1. Social power: control over others, dominance & 4.36 & $\alpha=.69$ \\
\hline & & 2. Wealth: material possessions, money & & \\
\hline & & 3. Authority: the right to lead or command & & \\
\hline & & 4. Influence: having an impact on people and events & & \\
\hline & & 5. Ambition: hard-working, aspiring & & \\
\hline & Biospheric value & $\begin{array}{l}\text { 1. Respecting the earth: live in harmony with other } \\
\text { species }\end{array}$ & 5.87 & $\alpha=.91$ \\
\hline & & 2. Preventing pollution: protecting natural resources & & \\
\hline & & 3. Protecting the environment: preserving nature & & \\
\hline & & 4. Unity with nature: fitting into nature & & \\
\hline
\end{tabular}

*1 =not important, $7=$ very important.

\subsubsection{Subjective Norm}

The subjective norm was adopted from the theory of reasoned action (Fishbein \& Ajzen, 1975). Using a 7-point Likert scale $(1=$ strongly disagree to $7=$ strongly agree $)$, respondents rated three statements: (a) Most people I know use energy-efficient light bulbs wherever possible; (b) Most people I know don't care whether I use energy-efficient bulbs; and (c) My family and friends expect me to use energy-efficient bulbs wherever it is possible. Item (b) was reverse-coded. The overall mean of the three items was 3.27 (S.D. $=1.21$ ), and the reliability of this aggregated scale was $\alpha=.65$.

\subsubsection{Lighting Perceptions}

Based on the Lighting Handbook of Illuminating Engineering Society of North America (2011) and Veitch and Gifford's (1996) study, respondents' perceived importance of lighting, perceived health effect of fluorescent lighting, and preference for incandescent lighting were measured.

Perceived importance of lighting was measured by asking participants to rate their agreement with five statements using a 7-point Likert scale $(1=$ strongly disagree to 7 = strongly agree): (a) The quality of light wherever I am is important to my well-being; (b) It makes no difference to me what kind of lighting is in a room; 
(c) Lighting is important to my mood; (d) Lighting is important to my work performance, and (e) As long as I can see to work, I don't care about the lighting in a room. Items (b) and (e) were reverse-coded. The overall mean of the five items was 5.53 (S.D. $=1.05$ ), and the reliability of this aggregated scale was $\alpha=.81$.

Perceived health effect of fluorescent lighting was measured by asking participants indicate their perceptions about the health effects of fluorescent light. Participants recorded their agreement with three items using a 7-point Likert scale $(1=$ strongly disagree to $7=$ strongly agree): (a) Fluorescent lights are bad for your health; (b) I get eyestrain from working under fluorescent lights; and (c) Fluorescent light gives me a headache. The overall mean of the three items was 3.28 (S.D. $=1.47$ ), and the reliability of this aggregated scale was $\alpha=.84$.

Preference for incandescent lighting was measured by asking participants to record their agreement with three survey items using a 7 -point Likert scale $(1=$ strongly disagree to $7=$ strongly agree): (a) Incandescent lights are attractive; (b), I like incandescent lights; and (c) Incandescent lights produce a warmer, more flattering color to people's appearances. The overall mean of the three items was 4.63 (S.D. $=1.05$ ), and the reliability of this aggregated scale was $\alpha=.79$.

The internal consistency reliability of each background variable was assessed using the Cronbach's alpha test. The results, with the exception of subjective norms $(\alpha=.65)$, fell above the cut-off of 0.7 (Nunnally, 1978), suggesting a satisfactory level of internal consistency for each construct.

\section{Results}

\subsection{Respondent Profiles}

Table 2 presents survey respondents' demographic characteristics. Among the 303 respondents, 128 were male (42.2\%) and 175 were female (57.8\%). Most respondents were Caucasian (91.7\%). The majority of respondents were above 45 years old: Approximately $61.7 \%$ of respondents were 45 to 64 years old and slightly more than $20 \%$ were 25 to 44 years old. About $17.2 \%$ of respondents were 65 years old or older. Just under half of the respondents $(44.2 \%)$ had some college education or had bachelor's degree, and slightly more than half of respondents $(53.5 \%)$ had a graduate or professional degree. The overall income of respondents was relatively high, with about half earning more than $\$ 100,000$ annually and about $32.7 \%$ earning $\$ 50,000$ to $\$ 99,999$ annually.

Table 2. Respondent profiles

\begin{tabular}{|c|c|}
\hline Demographics & Categories \\
\hline Gender & $\begin{array}{ll}\text { - } & \text { Male } 42.2 \%(n=128) \\
\text { - } & \text { Female } 57.8 \%(n=175)\end{array}$ \\
\hline Race & - $\quad 91.7 \%$ were Caucasian \\
\hline Age & $\begin{array}{ll}\cdot & 25-44 \text { year-old }(21.1 \%) \\
\text { - } & 45-64 \text { year-old }(61.7 \%) \\
\text { - } & 65 \text { year-old or older }(17.2 \%)\end{array}$ \\
\hline Education & $\begin{array}{ll}\text { - } & \text { High school or less }(2.3 \%) \\
\text { - } & \text { Some college or college graduates }(44.2 \%) \\
\text { - } & \text { Graduate or professional degree }(53.5 \%)\end{array}$ \\
\hline Income & $\begin{array}{ll}\text { - } & \$ 49,999 \text { or less }(20.8 \%) \\
\text { - } & \$ 50,000 \text { to } \$ 99,999(32.7 \%) \\
\text { - } & \$ 100,000 \text { or more }(46.5 \%)\end{array}$ \\
\hline
\end{tabular}


Table 3. Pearson's correlation coefficients among studied variables

\begin{tabular}{|c|c|c|c|c|c|c|c|c|c|c|}
\hline & B1 & B2 & B3 & B4 & V1 & V2 & V3 & SN & P1 & P2 \\
\hline \multicolumn{11}{|l|}{ B1 } \\
\hline B2 & $.275^{* *}$ & & & & & & & & & \\
\hline B3 & $.189^{* *}$ & $.453^{* *}$ & & & & & & & & \\
\hline B4 & $.190^{* * *}$ & $.429^{* * *}$ & $.558^{* * *}$ & & & & & & & \\
\hline V1 & $.220^{* * *}$ & $.313^{* * *}$ & $.434^{* *}$ & $.372^{* * *}$ & & & & & & \\
\hline V2 & -.013 & .069 & -.024 & .031 & .036 & & & & & \\
\hline V3 & $.246^{* *}$ & $.387^{* * *}$ & $.575^{* *}$ & $.446^{* *}$ & $.668^{* * *}$ & .040 & & & & \\
\hline SN & $.163^{* *}$ & $.385^{* *}$ & $.334^{* *}$ & $.364^{* *}$ & $.242^{* *}$ & -.038 & $.279^{* * *}$ & & & \\
\hline P1 & $.117^{*}$ & $.188^{* * *}$ & $.190^{* *}$ & .015 & $.262^{* * *}$ & .081 & $.333^{* * *}$ & .069 & & \\
\hline P2 & .034 & -.039 & -.005 & $-.145^{*}$ & -.030 & .000 & .002 & .078 & $.139^{*}$ & \\
\hline P3 & -.046 & -.092 & -.086 & $-.234^{* *}$ & -.017 & .053 & .001 & $-.123^{*}$ & $.267^{* * *}$ & $.212^{*}$ \\
\hline
\end{tabular}

Note 1. (B1)=Energy saving practice, $(\mathrm{B} 2)=$ Buying energy-efficient lighting, $(\mathrm{B} 3)=$ Willingness to pay higher price, (B4)=Supporting policy for energy efficient lighting, (V1)=Altruistic value, (V2)=Egoistic value, $(\mathrm{V} 3)=$ Biospheric value, $(\mathrm{SN})=$ Subjective Norms, $(\mathrm{P} 1)=$ Perceived importance of lighting, $(\mathrm{P} 2)=$ Perceived effects of fluorescent light on health, (P3)=Preference for incandescent lighting.

Note 2. ${ }^{*}$ Correlation is significant at the 0.01 level (2-tailed). ${ }^{*}$ Correlation is significant at the 0.05 level (2-tailed).

\subsection{Correlation Analysis}

To understand the relationships among different types of environmental behaviors, as well as between environmental behaviors and background variables, a Pearson's correlation coefficient test was applied (see Table 3). The tests examining relationships among different types of environmental behaviors showed that four different types of behaviors are moderately and positively correlated with each other, although energy-saving practice behavior is weakly associated with willingness to pay a higher price $(r=.189, p<.01)$ and support for lighting policy behavior $(r=.190, p<.01)$.

The tests examining relationships between behaviors and each of the background variables revealed that altruistic and biospheric values are positively related to all four types of environmental behaviors (all $p<.01$ ), whereas egoistic value is not significantly related to the behaviors. In addition, subjective norms are significantly and positively associated with all four types of lighting behaviors, although the correlation between subjective norms and energy-saving practices is smaller $(r=.163, p<.01)$ than the correlations between subjective norms and the remaining three lighting behaviors-namely, buying energy-efficient light $(r=.385)$, willingness to pay a higher price $(r=.334)$, and support for policy $(r=.364$; all $p<.01)$. The perceived importance of lighting is positively associated with energy-saving practice $(r=.117, p<.05)$, buying behavior $(r=.188, p<.01)$, and willingness to pay a higher price $(r=.190, p<.01)$. However, the perceived health effect on fluorescent light $(\mathrm{r}=-.145, p<.05)$ and preference for incandescent light $(\mathrm{r}=-.234, p<.01)$ are associated only with the support for policy behavior, not the other behaviors.

\subsection{Hypothesis Testing}

Independent-sample $t$-tests were conducted to test the hypotheses to identify whether any gender differences occurred in environmental behaviors in residential lighting practice and background variables. The results are presented in Table 4. 
Table 4. Gender differences in environmental behavior and its background variables

\begin{tabular}{|c|c|c|c|c|c|c|}
\hline & \multicolumn{4}{|c|}{ Gender } & \multicolumn{2}{|c|}{ t-test } \\
\hline & \multicolumn{2}{|c|}{ Men $(n=128)$} & \multicolumn{2}{|c|}{$\underline{\text { Women }(n=175)}$} & \multirow{2}{*}{ t-value } & \multirow{2}{*}{$\begin{array}{l}\text { two-tailed } \\
\text { significance }\end{array}$} \\
\hline & Mean & S.D. & Mean & S.D. & & \\
\hline \multicolumn{7}{|l|}{ Energy-efficient Lighting Behavior } \\
\hline Energy saving practices & 5.43 & 1.56 & 5.92 & 1.33 & $-2.88^{b}$ & $.004 * *$ \\
\hline Buying energy efficient lighting & 5.23 & 1.63 & 5.43 & 1.43 & $-1.12^{b}$ & .263 \\
\hline Willingness to pay higher price & 4.73 & 1.82 & 5.19 & 1.56 & $-2.30^{b}$ & $.022 *$ \\
\hline Supporting policy & 3.93 & 2.23 & 3.77 & 2.07 & $0.64^{\mathrm{a}}$ & .525 \\
\hline \multicolumn{7}{|l|}{ Ecological Value Orientation } \\
\hline Altruistic value & 5.72 & 0.97 & 6.04 & 0.88 & $-3.04^{\mathrm{a}}$ & $.003 * *$ \\
\hline Egoistic value & 4.42 & 0.91 & 4.31 & 0.93 & $1.02^{\mathrm{a}}$ & .307 \\
\hline Biospheric value & 5.67 & 1.11 & 6.02 & 0.96 & $-2.87^{b}$ & $.004^{* *}$ \\
\hline \multicolumn{7}{|l|}{ Subjective Norms } \\
\hline Subjective norms & 3.08 & 1.13 & 3.42 & 1.26 & $-2.40^{\mathrm{a}}$ & $.017^{*}$ \\
\hline \multicolumn{7}{|l|}{ Lighting Perception } \\
\hline Perceived Importance of lighting & 5.18 & 1.13 & 5.79 & 0.92 & $-5.02^{b}$ & $.000^{* * *}$ \\
\hline $\begin{array}{l}\text { Perceived effects of fluorescent } \\
\text { light on health }\end{array}$ & 2.85 & 1.39 & 3.58 & 1.45 & $-4.40^{\mathrm{a}}$ & $.000 * * *$ \\
\hline $\begin{array}{l}\text { Preference for Incandescent } \\
\text { lighting }\end{array}$ & 4.34 & 0.99 & 4.85 & 1.05 & $-4.30^{\mathrm{b}}$ & $.000 * * *$ \\
\hline
\end{tabular}

Note: ${ }^{\mathrm{a}}$ equal variance estimate; ${ }^{\mathrm{b}}$ Unequal variance estimate.

$* \mathrm{p}<.05 ; * * \mathrm{p}<.01 ; * * * \mathrm{p}<.001$.

Prior to conduct independent-sample $t$-test, the normality of variables for two groups (i.e., men and women) was examined in terms of skewness and kurtosis. The symmetry of the distribution was checked with skewness while kurtosis was examined to measure whether the data are peaked or flat relative to a normal distribution. A skewness value above three is conventionally considered as extremely skewed and a kurtosis value of 10 is a conventional criterion indicating normality distribution in terms of its peakedness (Hair, Anderson, Tathan, \& Black, 1998). Since values of skewness and kurtosis for all variables were found to fall within the convential criteria of normality (i.e., -3 to 3 for skewness, -10 to 10 for kurtosis), inpendent-sample $t$-tests were conducted rather than using a non-parametic test such as Mann-Whitney $\mathrm{U}$ test.

Hypothesis 1 tested gender differences in environmental behaviors in residential lighting practices. The results indicated that women scored significantly higher in energy-saving practices: $t(247.770)=-2.88, p<.01$ as well as a willingness to pay a higher price: $t(248.253)=-2.30, p<.05$. Yet no evidence suggested a gender difference in the purchase of energy-efficient lighting and support for policy. Although the mean differences between men and women were not significant, women $(M=5.43)$ reported a higher score on buying energy-efficient lighting product than men $(M=5.23)$ whereas men $(M=3.93)$ had a higher score on supporting policy than women $(M=3.77)$.

Hypothesis 2 tested gender differences in ecological value orientations. Women scored significantly higher in altruistic value $(t[301]=-3.04, p<.01)$ and biospheric value $(t[248.267]=-2.87, p<.01)$. However, no evidence of a gender difference in egoistic value emerged. Although the mean difference between gender groups was not statistically significant, men $(M=4.42)$ had a slightly higher score on egoistic value than women $(M=4.31)$.

Hypothesis 3 tested gender differences in subjective norms. Compared to men $(M=3.08, \mathrm{SD}=1.13)$, women $(M=3.42, \mathrm{SD}=1.26)$ scored higher on subjective norms: $t(301)=-2.40, p<.05$. Finally, Hypothesis 4 tested gender differences in lighting perceptions. Women scored significantly higher in perceived importance of lighting $(t[238.57]=-5.02, p<.001)$, preference for incandescent light $(t[283.35]=-4.40, p<.001)$, and perceived negative effects of fluorescent light on health $(t[301]=4.40, p<.001)$. 


\section{Discussion}

Given that the issue of gender has not been central to the study of residential consumers' adoption of energy-efficient lighting, this study explored whether a gender difference exists in residential consumers' (1) pro-environmental behaviors in residential lighting practice based on Dietz, Stern, and Guagnano (1998) and Stern (2000), (2) ecological value orientation based on VBN theory (Stern et al., 1999), (3) subjective norms based on the theory of reasoned action (Fishbein \& Ajzen, 1975), and (4) lighting perceptions (Veitch \& Gifford, 1996). The findings revealed significant gender differences in residential consumers' environmental behaviors as well as background variables, providing theoretical implications for consumers' pro-environmental behaviors in addition to practical implications for promoting households' adoption of energy-efficient lighting.

Consistent with previous studies (Eisenberg, 2002; Schultz, 2001; Stern et al., 1993), the findings demonstrated that women had higher pro-environmental value orientation and put more importance on helping others in their life than men, thereby indicating significantly higher altruistic and biospheric values than men. Given that egoistic value orientation did not show significant gender differences, which is inconsistent with the studies of Schultz (2001) and Stern et al. (1993), women are more concerned about environmental problems (Lee, 2009; Tikka et al., 2000; Zelezney et al., 2000) because they put their concern about the welfare of other people and impacts on ecological systems ahead of their personal benefits. As gender socialization theory and ecofeminists have indicated, women might care more about the environment because they are socialized to the role of caretakers (Eisenberg, 2003; Gilligan, 1982). As women are responsible for childcare and housework, their roles as family caretakers might lead to greater concerns for the environment for others and ecosystem. Considering that more than $80 \%$ of survey respondents were over 35 years old, women with children might be more concerned about environmental problems than men because of their increased attentiveness to environmental consequences, as Stern et al. (1993) claimed.

In line with the studies of Lee (2009) and Venkatesh and Morris (2000), this study found that women were more influenced by peers in terms of their use of energy-efficient lighting for their home. Venkatesh and Morris (2000) highlighted the significant influence of subjective norms in women's decision making in technology adoption, and the findings of the current study indicated that women were significantly influenced by subjective norms in behavioral decisions on the adoption of energy-efficient lighting. This result implies that promotion strategies for residential consumers' adoption of energy-efficient lighting should not be limited to the private sector, but rather extensively encompass all sectors. Residential consumers' subjective norms might act as a catalyst and effectively impact residential consumers' decision-making process in the adoption of energy-efficient lighting.

In terms of environmental behaviors in residential lighting practice, this study tested gender differences in two household-oriented private environmental behaviors (i.e., energy-saving practice and purchase of energy-efficient lighting) and two community/society-oriented environmental behaviors (i.e., willingness to pay a higher price and support of policy) based on Hunter et al. (2004) and Stern (2004). Many previous studies (Hunter et al., 2004; Xiao \& Hong, 2010) have indicated that women engage in more household-oriented (private) environmental behaviors than men while generally no gender difference exists in community/society-oriented behaviors. However, the results of the current study were inconsistent with these previous studies. For the household-oriented private environmental behaviors, women showed higher participation in energy-saving practices at home as many previous studies have indicated that women littered less (Kallgren, Reno, \& Cialdini, 2000) and recycled more (Zelezny et al., 2000), but women did not show higher participation in the purchase of energy-efficient lighting. For the community/society-oriented environmental behaviors, women had a stronger willingness to pay a higher price for energy-efficient lighting than men, whereas no gender difference was shown in support for policy banning incandescent lighting.

The inconsistency in women's environmental behaviors, showing no gender difference in actual purchase behavior despite their greater willingness to pay a higher price, could be related to their lighting perceptions. The reason for women's lower involvement in buying energy-efficient lights for their homes could be explained by their perceived importance of lighting, perceived health effects of fluorescent lighting, and preference for incandescent light. Women perceived interior lighting to be important to their well-being, work performance, and mood more strongly than men did. Women strongly preferred incandescent lighting and believed incandescent lighting is more aesthetically attractive and produces a more flattering color to people's appearance. In addition, women were more likely to believe that fluorescent lighting was harmful to their health. As Veitch and Gifford (1996) indicated, women's preference for incandescent lights and their negative perceptions about the quality of energy-efficient lighting might still hinder their adoption of energy-efficient home lighting.

The findings indicated that, although consumers show strong ecological value orientations, actual buying 
behavior was not directly related. According to Corraliza and Berenguer (2000), people tend to engage in environmentally responsible behaviors out of a sense of moral obligation only when their environmental attitude does not conflict with other favorable situations. Women's preference for incandescent lighting and their lack of confidence about the quality of energy-efficient lighting might affect their actual purchase of energy-efficient home lighting regardless of their ecological value orientation.

\section{Conclusion and Policy Implications}

Women can play a critical role in the adoption of energy-efficient lighting for their home, because women are generally responsible for buying about $80 \%$ of household goods (Barletta, 2003; Griffin, 2006). According to Banwell, Brons, Freyssinier-Nova, Pizzo, and Figueiro (2004), the quality of energy-efficient lighting was rated as "equivalent to or better" than the incandescent lighting by visitors to the designer showcase home in regard to color appearance, brightness, and visual comfort. However, limited knowledge about the benefits of energy-efficient lighting and the lack of information about the advanced quality of energy-efficient lighting were key barriers to the adoption of energy-efficient lighting at home (Banwell \& Figueiro, 2005; Conway \& Mehra, 1998; Winchip, 2008).

To avoid misunderstanding about the quality of energy-efficient lighting, policy makers and marketers should pay attention to the delivery of objective and accurate information about lighting to consumers, particularly female consumers (Veitch, Hine, \& Gifford, 1993). Marketing strategies promoting the use of energy-efficient lighting should emphasize areas that would interest each gender. Designers and builders should be aware of gender differences when working with their clients and emphasize the benefits of energy-efficient lighting to their female clients as well as provide updated technological quality. Government and lighting researchers should, for example, use model homes to showcase new energy-efficient lighting fixtures to publicize new lighting technologies and prevent further misconceptions about lighting (Veitch et al., 1993).

However, the findings of this study should be cautiously applied because the sample of this study might not represent the general American population. Although a systematic random sampling was used to select the sample, the subjects were chosen from a small town in the Midwest. The subjects' income and educational level were higher than the national average. Future researchers should investigate the role of gender on environmental behaviors and background variables of environmental behaviors with people with average incomes and education in other areas of the United States. In addition, as this study explored gender issues in environmental behavior with American samples, the results of the study would become significantly different for studies conducted in different nations. As gender roles and values differ from society to society, applying the results of gender study into practice should be limited within the studied population. This study focused on only fluorescent lighting and CFL as energy-efficient lighting. However, given that LED lighting is considered to be the most promising lighting technology, it is recommended to focus on the adoption of LED lighting for residential customers in future studies.

\section{References}

Ajzen, I. (1985). From intentions to actions: A theory of planned behavior. In J. Kuh \& J. Beckmann (Eds.), Action control: From cognition to behavior (pp. 11-39). Berlin: Springer-Verlag.

Alreck, P., \& Settle, R. (1995). Survey research handbook (2nd ed.). New York, NY: McGraw-Hill.

Banwell, P., Brons, J., Freyssinier-Nova, J. P., Pizzo, P., \& Figueiro, M. (2004). A demonstration of energy-efficient lighting in residential new construction. Lighting Research and Technology, 36, 147-164. http://dx.doi.org/10.1191/1365782804li110oa

Banwell, P., \& Figueiro, M. (2005). Overcoming the myths of energy-efficient lighting in residential applications. Proceedings of the Right Light 6: The International Association for Energy Efficient Lighting (IAEEL). Shanghai, China.

Barletta, M. (2003). Marketing to women: How to understand, reach, and increase your share of the world's largest market segment. Chicago: Dearborn Trade Publishing.

Berenguer, J., Corraliza, J. A., \& Martin, R. (2005). Rural-urban differences in environmental concern, attitudes, and actions. European Journal of Psychological Assessment, 21(2), 128-138. http://dx.doi.org/10.1027/1015-5759.21.2.128

Blankenau, J., Snowden, M., \& Langan, M. (2008). Understanding environmentalism in a red, agricultural state: The impact of political party identification and place of residence. Sociological Spectrum, 28(1), 55-80. http://dx.doi.org/10.1080/02732170701675201 
Blocker, T. J., \& Eckberg, D. L. (1997). Gender and environmentalism: Results from the 1993 general social survey. Social Science Quarterly, 78(4), 841-858. Retrieved from http://web.ebscohost.com.proxy1.cl.msu.edu/ehost/pdfviewer/pdfviewer?vid=3\&sid=ed63b94b-7a91-444bb648-75b9b828c6f0\%40sessionmgr11\&hid=21

Carlsson-Kanyama, A., \& Lindén, A. L. (2007). Energy efficiency in residences-challenges for women and men in the North. Energy Policy, 35(4), 2163-2172. http://dx.doi.org/10.1016/j.enpol.2006.06.018

Casey,P. J., \& Scott, K. (2006). Environmental concern and behavior in an Australian sample within an ecocentric-anthropocentric framework. Australian Journal of Psychology, 58(2), 57-67. http://dx.doi.org/10.1080/00049530600730419

Cheung, S. F., Chan, D. K. S., \& Wong, Z. S. Y. (1999). Reexamining the Theory of Planned Behavior in understanding wastepaper recycling. Environment and Behavior, 31(5), 587-612. http://dx.doi.org/10.1177/00139169921972254

Conway, K. M., \& Mehra, M. (1998). Lighting market opportunities: reconciling consumers' purchasing behaviors with environmental values. Journal of Illuminating Engineering Society, 27, 67-76.

Corbett, J. B. (2005). Altruism, self-interest, and the reasonable person model of environmentally responsible behavior. Science Communication, 26(4), 368-389. http://dx.doi.org/ 10.1177/1075547005275425

Corraliza, J. A., \& Berenguer, J. (2000). Environmental values, beliefs, and actions: a situational approach. Environment and Behavior, 32(6), 832-848. http://dx.doi.ort/ 10.1177/00139160021972829

Diamond, I., \& Orenstein, G. F. (Eds.). (1990). Reweaving the world: The emergence of ecofeminism. San Francisco: Sierra Club Books.

Dietz, T., Stern, P. C., \& Guagnano, G. A. (1998). Social structural and social psychological bases of environmental concern. Environment and Behavior, 30(4), 450-471. http://dx.doi.org/10.1177/001391659803000402

Eisenberg, N. (2002). Empathy-related emotional responses, altruism, and their socialization. In R. J. Davidson \& A. Harrington (Eds.), Visions of compassion: Western scientists and Tibetan Buddhists examine human nature (pp. 131-164). http://dx.doi.org/10.1093/acprof:oso/9780195130430.003.0007

Eisler, A. D., Eisler, H., \& Yoshida, M. (2003). Perception of human Ecology: Cross-cultural and gender $\begin{array}{llll}\text { comparisons. Journal of Environmental Psychology, } & \text { 23(1), }\end{array}$ http://dx.doi.org.proxy1.cl.msu.edu/10.1016/S0272-4944(02)00083-X

Fishbein, M., \& Ajzen, I. (1975). Belief, attitude, intention and behavior. Reading, Massachusetts: Addison-Wesley.

Gilg, A., Barr, S., \& Ford, N. (2005). Green consumption or sustainable lifestyles? Identifying the sustainable consumer. Futures, 37(6), 481-504. http://dx.doi.org/ 10.1016/j.futures.2004.10.016

Gilligan, C. (1982). In a different voice. Cambridge, MA: Harvard University Press.

Griffin, C. (2006). Feminine mystique. SGB, 39(3), 18-19. Retrieved from http://web.ebscohost.com.Proxy1. cl.msu.edu/ehost/detail?vid=3\&sid=3e388523-935a-449a-93b2-105122ab3db3\%40sessionmgr11\&hid=21\&

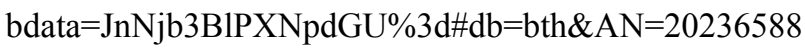

Hair, J. F., Anderson, R. E., Tatham, R. L., \& Black, W. C. (1998). Multivariate data analysis with readings (5th Edition). Upper Saddle River, NJ: Prentice-Hall International.

Heinzle, S., Kanzig, J., Nentwich, J., \& Offenberger, U. (2010). Moving beyond gender differences in research on sustainable consumption: Evidence from a discrete choice experiment. Working paper No. 6 within the project Soziale, ökologische und ökonomische Dimensionen eines nachhaltigen Energiekonsums in Wohngebäuden. Retrieved Februay 20, 2013 from http://kooperationen.zew.de/fileadmin/user_upload/ Redaktion/Seco@home/nachhaltiger_Energiekonsum/Werkstattberichte/Gender_Werkstattbericht6.pdf

Hunter, L. M., Hatch, A., \& Johnson, A. (2004). Cross-national gender variation in environmental behaviors. Social Science Quarterly, 85(3), 677-694. http://dx.doi.org/10.1111/j.0038-4941.2004.00239.x

Iluminating Engineering Society of North America (IESNA). (2011). Lighting handbook (10th ed.). New York: IESNA.

Jakob, M. (2007). Modeling the choice of renovation modes of single family home owners with respect to energy-efficiency, Paper presented at the 15th EAERE Annual Conference, University of Macedonia, 
Thessaloniki, Greece, 27-30 June 2007.

Johnson, C. Y., Bowker, J. M., \& Cordell, H. K. (2004). Ethnic variation in environmental belief and behavior: An examination of the new ecological paradigm in a social psychological context. Environment and Behavior, 36(2), 157-186. http://dx.doi.org/ 10.1177/0013916503251478

Kaiser, F. G. (2006). A moral extension of the theory of planned behavior: Norms and anticipated feelings of regret in conservationism. Personality and Individual Differences, 41, 71-81. http://dx.doi.org/10.1016/j.paid.2005.11.028

Kallgren, C. A., Reno, R. R., \& Cialdini, R. B. (2000). A focus theory of normative conduct: When norms do and do not affect behavior. Personality and Social Psychology Bulletin, 26(8), 1002-1012. http://dx.doi.org/10.1177/01461672002610009

Knez, I. (1995). Effects of indoor lighting on mood and cognition. Journal of Environmental Psychology, 15, 39-51. http://dx.doi.org/10.1016/0272-4944(95)90013-6

Knez, I., \& Kers, C. (2000). Effects of indoor lighting, gender, and age on mood and cognitive performance. Environment and Behavior, 32(6), 817-831. http://dx.doi.org/ 10.1177/0013916500326005

Kollmuss, A., \& Agyeman, J. (2002). Mind the gap: Why people act environmentally and what are the barriers to environmentally-friendly behavior. Environmental Education Research, 8(3), 239-260. http://dx.doi.org/10.1080/13504620220145401

Lee, K. (2009). Gender differences in Hong Kong adolescent consumers' green purchasing behavior. Journal of Consumer Marketing, 26, 87-96. http://dx.doi.org/10.1108/07363760910940456

Leslie, R. P., \& Hartleb, S. B. (1990). Human response and variability in the luminous environment. Proceedings of the CIBSE National Lighting Conference, Cambridge, England, 8-11 April 1990 (pp. 87-99). London, UK: Chartered Institution of Building Services Engineers.

Manzan, S., \& Zerom, D. (2006). A semiparametric analysis of gasoline demand in the US: Reexamining the impact of price. Econometric Reviews, 29(4), 439-468. Retrieved from http://mpra.ub.uni-muenchende/14386/

Matthies, E., Kuhn, S., \& Klockner, C. (2002). Travel mode choice of women: The result of limitation, ecological norm, or weak habit? Environment and Behavior, 34(2), 163-177. http://dx.doi.org/10.1177/0013916502034002001

Mills, B., \& Schleich, J. (2012). Residential energy-efficient technology adoption, energy conservation, knowledge, and attitudes: An analysis of European countries. Energy Policy, 49, 616-628. http://dx.doi.org/10.1016/j.enpol.2012.07.008

Mostafa, M. M. (2007). Gender differences in Egyptian consumers' green purchase behavior: The effects of environmental knowledge, concern and attitude. International Journal of Consumer Studies, 31, $220-229$. http://dx.doi.org/ 10.1111/j.1470-6431.2006.00523.x

Nunnally, J. C. (1978). Psychometric theory (2nd ed.). McGraw-Hill Book Company.

Parikh, J. K. (1995). Gender issues in energy policy. Energy Policy, 23(9), $745-754$. http://dx.doi.org.proxy1.cl.msu.edu/10.1016/0301-4215(95)00056-O

Räty, R., \& Carlsson-Kanyama, A. (2010). Energy consumption by gender in some European countries. Energy Policy, 38(1), 646-649. http://dx.doi.org.proxy1.cl.msu.edu/10.1016/j.enpol.2009.08.010

Rehdanz, K. (2007). Determinants of residential space heating expenditures in Germany. Energy Economics, 29, 167-182. http://dx.doi.org/10.1016/j.eneco.2006.04.002

Reynolds, T., DeSisto, T., Murray, B., \& Kolodinsky, J. (2007). Promoting energy efficiency in small island states: Overcoming barriers to the adoption of compact fluorescent lighting in Saint Lucia. International Journal of Consumer Studies, 31, 460-467. http://dx.doi.org/ 10.1111/j.1470-6431.2007.00594.x

Rokeach, M. (1973). The nature of human values. New York: Free Press.

Schepers, J., \& Wetzels, M. (2007). A meta-analysis of the technology acceptance model: Investigating subjective norm and moderation effects. Information \& Management, 44, 90-103. http://dx.doi.org/10.1016/j.im.2006.10.007

Schultz, P. W. (2001). The structure of environmental concern: Concern for self, other people, and the biosphere. Journal of Environmental Psychology, 21, 327-339. http://dx.doi.org/10.1006/jevp.2001.0227 
Schwartz, S. H. (1977). Normative influences on altruism. In L. Berkowitz (Ed.), Advances in experimental social psychology (Vol. 10, pp. 221-279). New York: Academic Press.

Scott, D., \& Willits, F. K. (1994). Environmental attitudes and behavior: A Pennsylvania survey. Environment and Behavior, 26, 239-260. http://dx.doi.org/10.1177/001391659402600206

Shen, J. Y., \& Saijo, T. (2008). Reexamining the relations between socio-demographic characteristics and individual environmental concern: Evidence from Shanghai data. Journal of Environmental Psychology, 28, 42-50. http://dx.doi.org/10.1016/j.jenvp.2007.10.003

Sherkat, D. E., \& Ellison, C. G. (2007). Structuring the religion-environment connection: Identifying religious influences on environmental concern and activism. Journal of the Scientific Study of Religion, 46(1), 71-85. http://dx.doi.org/ 10.1111/j.1468-5906.2007.00341.x

Steg, L. (2008). Promoting household energy conservation. Energy Policy, 36(12), 4449-4453. http://dx.doi.org.proxy1.cl.msu.edu/10.1016/j.enpol.2008.09.027

Stern, P. C. (2000). Toward a coherent theory of environmentally significant behavior. Journal of Social Issues, 56, 407-424. http://dx.doi.org/10.1111/0022-4537.00175

Stern, P. C., Dietz, T., Abel, T., Guagnano, G. A. \& Kalof, L. (1999). A value-belief-norm theory of support for social movements: The case of environmentalism. Research in Human Ecology, 6, 81-97. Retrieved from http://www.humanecologyreview.org/pastissues/her62/62sternetal.pdf

Stern, P. C., Dietz, T., \& Kalof, L. (1993). Value orientations, gender, and environmental concern. Environment and Behavior, 25(5), 322-348. http://dx.doi.org/ 10.1177/0013916593255002

Swimi, V., Chamorro-Premuzic, T., Snelgar, R., \& Furnham, A. (2010). Egoistic, altruistic, and biospheric environmental concerns: A path analytic investigation of their determinants. Scandinavian Journal of Psychology, 51, 139-145. http://dx.doi.org/10.1111/j.1467-9450.2009.00760.x

Tikka, P. M., Kuitunen, M. T., \& Tynys, S. M. (2000). Effects of educational background on students' attitudes, activity levels, and knowledge concerning the environment. Journal of Environmental Education, 31, 12-19. http://dx.doi.org/ 10.1080/00958960009598640

Torgler, B., García -Valiñas, M. A., \& Macintyre, A. (2008). Differences in preferences towards the environment: The impact of a gender, age and parental effect. Working paper No. 2008-1, Center for Research in economics, Management, and the Arts, Basel. Retrieved from http://ageconsearch.umn.edu/bitstream/6371/2/080018.pdf

U.S. Department of Energy (DOE). (2012). 2010 U.S. lighting market characterization. Retrieved July 4, 2012 from http://apps1.eere.energy.gov/buildings/publications/pdfs/ss1/2010-lmc-final-jan-2012.pdf

Veitch, J. A., \& Gifford, R. (1996). Assessing beliefs about lighting effects on health, performance, mood, and $\begin{array}{llll}\text { social behavior. Environment and } & \text { Behavior, }\end{array}$ http://dx.doi.org/10.1111/j.1939-1668.1993.tb00148.x

Veitch, J. A., Hine, D. W., \& Gifford, R., (1993). End users' knowledge, beliefs, and preferences for lighting. Journal of Interior Design, 19(1), 15-26. http://dx.doi.org/10.1111/j.1939-1668.1993.tb00159.x

Venkatesh, V., \& Morris, M. G. (2000). Why don't men ever stop to ask for directions? Gender, social influence, and their role in technology acceptance and usage Behavior. MIS Quarterly, 24(1), 115-139. http://dx.doi.org/10.2307/3250981

Vinz, D. (2009). Gender and sustainable consumption: A German environmental perspective. European Journal of Women's Studies, 16(2), 159-179. http://dx.doi.org/10.1177/1350506808101764

Wall, R., Devine-Wright, P., \& Mill, G. A. (2007). Comparing and combining theories to explain Pro-environmental intentions: The case of commuting-mode choice. Environment and Behavior, 39(6), 731-753. http://dx.doi.org/10.1177/0013916506294594

Wehrmeyer, W., \& McNeil, M. (2000). Activists, pragmatists, technophiles and tree-huggers? Gender differences in employees' environmental attitudes. Journal of Business Ethics, 28(3), 211-222. http://dx.doi.org/10.1023/A:1006253212744

Winchip, S. M. (2008). Designing a quality lighting environment. New York: Fairchild Publications Inc.

Xiao, C., \& Hong, D. (2010). Gender differences in environmental behaviors in China, Population and Environment, 32, 88-104. http://dx.doi.org/10.1007/s11111-010-0115-z 
Yildirim, K., Akalin-Baskaya, A., \& Hidayetoglu, M. L. (2007). Effects of indoor color on mood and cognitive performance. Building and
http://dx.doi.org/10.1016/j.buildenv.2006.07.037

Zelezny, L. C., Chua, P. P., \& Aldrich, C. (2000). New ways of thinking about environmentalism: Elaborating on gender differences in environmentalism. Journal of Social Issues, 56, 443-457. http://dx.doi.org/10.1111/0022-4537.00177

\section{Copyrights}

Copyright for this article is retained by the author(s), with first publication rights granted to the journal.

This is an open-access article distributed under the terms and conditions of the Creative Commons Attribution license (http://creativecommons.org/licenses/by/3.0/). 